\title{
Editorial
}

\section{Nanotechnology for making a paradigm shift in COVID-19 vaccine}

\author{
Dibya Sundar Panda', Dr. Mohammad Khursheed Alam ${ }^{2}$, Prof. Abu Kholdun Al-Mahmod ${ }^{3}$
}

Bangladesh Journal of Medical Science, Special Issue on COVID-19. 2021. Page : 5-7

DOI: https://doi.org/10.3329/bjms.v21i1.56321

The boon of biomedical research is vaccine. Vaccine is an economical means of protecting people's life from infectious diseases. The vaccines must be safe, stable and effective in developing required level of immunity for a long period of time with minimum doses 1. Many approaches havebeen applied in developing vaccines for COVID-19, which are as follows.

- Attenuated virus devoid of virulence with sufficient antigenicity.

- Vaccines containing parts of protein or protein shell, simulating COVID-19 virus, and producing immune response safely.

- Viral vector vaccines, work as a stage for protein synthesis of coronavirus mediating immune response safely.

- $\quad$ RNA and DNA vaccines, genetically engineered nucleic acids, which synthesizes protein mediating quick immune response safely.

RNA and DNA vaccines are capable of developing immunity against specific pathogen with less chance of infection economically. Many challenge lies in delivering them to the site of action along with other immunogens as a part of vaccination regimen.
They are like untimely destruction of molecules and failure in converting into working immunogen ${ }^{2}$. Protein containing vaccines are effective against infectiouscaused by Haemophilus influenza type b, diphtheria, tetanus, acellular pertusis, meningococcus and pneumococcus ${ }^{3}$ but need adjuvant to fortify their immunogenicity, and suffer fromearly destruction. The aforementioned drawbacks can be encountered with the use of effective delivery system, that can deliver the vaccine at the target site along with adjuvant if needed, protecting it from the degradation in hostile environment. The delivery system should produce lingering immunogenic effect without any side effects. Nano delivery systems could fulfill the above requirements and can exhibit sustained release of the vaccine molecules without getting harmed by proteases. Surface adsorption enables cognate surface receptor interaction ${ }^{4}$. Using nanocarriers for vaccine molecules enhances cellular uptake leading to potentiation of innate, humoral, cellular and mucosal immune responses ${ }^{5}$.Currently approved Covid-19 vaccine for use are given in table 1.

1. Dibya Sundar Panda , Pharmaceutics Department, College of Pharmacy, Jouf University, E.mail: dibyapanda1974@gmail.com

2. Dr. Mohammad Khursheed Alam, Professor, Orthodontic Division, Preventive Dentistry Department, College of Dentistry, Jouf University. Sakaka, Al Jouf, KSA.

3. Prof. Abu Kholdun Al-Mahmod, Professor, Department of Biochemistry, IbnSina Medical College, Dhaka.ORCID ID : https://orcid.org.0000-0002-5474-4481, SCOPUS ID : 12809783500, ResearchGate ID : 2027055323

Correspondence: Dr. Mohammad Khursheed Alam PhD in Orthodontics [Japan], Professor, Orthodontic Division, Preventive Dentistry Department, College of Dentistry, Jouf University. Sakaka, Al Jouf, KSA. E-mail: dralam@gmail.com\&mkalam@ju.edu.sa 
Table 1 Approved list of COVID-19 vaccine (Jan et al, 2021)

\begin{tabular}{|c|c|c|c|c|c|}
\hline Manufacturer & Vaccine & Type & $\begin{array}{l}\text { Number } \\
\text { of dose }\end{array}$ & $\begin{array}{c}\text { Time } \\
\text { interval }\end{array}$ & Efficiency \% \\
\hline Pfizer & BNT162b2 & mRNA & 2 & 21 days & 95 \\
\hline Moderna & COVID-19 Vaccine & mRNA & 2 & 28 days & 94.1 \\
\hline AstraZeneca/SKBio & $\begin{array}{l}\text { ChAdOx1-S } \\
\text { [recombinant] }\end{array}$ & $\begin{array}{l}\text { Chimpanzee } \\
\text { adenovirus }\end{array}$ & 2 & 12 weeks & 82 \\
\hline Serum Institute of India Pvt Ltd & $\begin{array}{l}\text { ChAdOx1-S } \\
\text { [recombinant] }\end{array}$ & $\begin{array}{l}\text { Chimpanzee } \\
\text { adenovirus }\end{array}$ & 2 & 12 weeks & 82 \\
\hline Johnson \& Johnson & $\operatorname{Ad} 26$ & adenovirus & - & - & 66 \\
\hline $\begin{array}{c}\text { Gamaleya National Research Centre for } \\
\text { Epidemiology and Microbiology }\end{array}$ & $\begin{array}{l}\text { (Gam-COVID- } \\
\text { Vac) }\end{array}$ & $\begin{array}{l}\text { Heterologous } \\
\text { recombinant } \\
\text { adenovirus }\end{array}$ & - & - & 91.6 \\
\hline Beijing Institute of Biotechnology & CanSinoBIO Ad5 & Adenovirus & - & - & 90.07 \\
\hline
\end{tabular}

Nanoparticle vaccine are effective, safe and easy to prepare. Attenuated virus vaccine are more effective in comparison to vaccines containing parts of virus but has a lengthy production time, needs storage at subzero temperature and has the risk of side effects. Nucleic acid(RNA and DNA) containing vaccines are quick to produce but costly and may need more than one dose.There are reports about the successful immune response of nanoparticle vaccines for COVID-19 in mice following a single dose. The researcher are making efforts to ease its storage condition by preparing them in freeze-dried form, which will facilitates its transport ${ }^{6}$.

\section{Nanoparticles of spikes}

SARS-CoV-2, spike protein is bigger in size, researchers are attempting to condense it which will be easy and convenient to use. The vaccine has been prepared by combining condensed spike with ferritin nanoparticles tested before in humans.

Researchers have tested the condensed spike nanoparticles along with another four candidates nanoparticles containing full spike, full or part spikes, part of the spike binding to cells during infection in the mouse.

Solo dose of two nanoparticle vaccines produced antibodies double of that seen in COVID-19 infected people, the condensed spike nanoparticle vaccine shown a significantly greater neutralizing reactionin contrast to the binding spike or the full spike containing vaccines. Following the subsequent dose, mice that got the condensed spike nanoparticle vaccine had the utmost levels of neutralizing antibodies?

COVID-19 rising to unprecedented levels ${ }^{8,9}, 10$, preparation of nanoparticle vaccine can offer many solutions to overcome the associated problems of currently approved COVID-19 vaccine.

Source of fund: (if any). None

Conflict of interest: None

Ethical clearance: NA

Authors's contribution: Equally contributed. 


\section{References}

1. Ada GL. The ideal vaccine. World $J$ Microbiol Biotechnol. (1991) 7:105-9. doi: 10.1007/BF00328978

2. Donnelly JJ, Wahren B, Liu MA. DNA vaccines: progress and challenges. J Immunol. 2005; 175:633-9. doi: 10.4049/jimmunol.175.2.633

3. Skibinski DA, Baudner BC, Singh M, O’Hagan DT. Combination vaccines. J Glob Infect Dis. 2011; 3:63-72. doi: 10.4103/0974-777X.77298

4. Means TK, Hayashi F, Smith KD, Aderem A, Luster AD. The Toll-like receptor 5 stimulus bacterial flagellin induces maturation and chemokine production in human dendritic cells. J Immunol. 2003; 170:5165-75. doi: 10.4049/jimmunol.170.10.5165

5. Pati R, Shevtsov $M$ and Sonawane A Nanoparticle Vaccines against Infectious Diseases. Front. Immunol. 2018; 9:2224. doi: 10.3389/fimmu.2018.02224

6. Stanford University. "Nanoparticle vaccine for COVID-19." ScienceDaily. ScienceDaily, 8 January 2021. <www.sciencedaily.com/ releases/2021/01/210108142138.htm>.
7. Abigail E. Powell, Kaiming Zhang, Mrinmoy Sanyal, Shaogeng Tang, Payton A. Weidenbacher, Shanshan Li, Tho D. Pham, John E. Pak, Wah Chiu, Peter S. Kim. A Single Immunization with Spike-Functionalized Ferritin Vaccines Elicits Neutralizing Antibody Responses againstSARS-CoV-2 in Mice. ACS Central Science, 2021; DOI: $10.1021 /$ acscentsci.0c01405

8. W Ahmad, W. M. A., Nawi, M. A. A., Zainon, W. M. N. W., Mohd Noor, N. F., Mohd Hamzah, F., Mohamad Ghazali, F. M., \& Alam, M. K.. Forecasting cumulative COVID-19 cases in Malaysia and rising to unprecedented levels. Bangladesh Journal of Medical Science, 2021; 20(3), 504-510. https://doi.org/10.3329/ bjms.v20i3.52791

9. Khan, M. G., Yezdani, U., Chakravorty, A., \& Shukla, T. Efforts and Challenges paved by India to confront of Corona Virus (COVID-19). Bangladesh Journal of Medical Science, 2020; 19, S 88-S 92. https://doi. org/10.3329/bjms.v19i0.48198

10. Ahmad R. SARS-CoV-2 Immunity: Review of Immune Response to Infection and Vaccination. Bangladesh Journal of Medical Science, 2021; 20(5), 32-40. https:// doi.org/10.3329/bjms.v20i5.55398 